\title{
FLUJO GENICO HORIZONTAL EN MICROORGANISMOS: ALGUNOS AVANCES ACTUALES
}

\section{Horizontal gene flux in microorganisms: some recent advances}

\author{
James Robesom \\ Instituto de Biología \\ Universidad Católica de Valparaíso \\ Avenida Brasil 2950, Valparaíso, Chile \\ Fono: 251024 Anexo 3242 - Fax: 212746 \\ E.mail: jrobeson@aix1.ucv.cl
}

Palabras clave: Flujo génico, conjugación, plásmidos. Key words: Gene flux, conjugation, plasmids.

El proceso de flujo génico horizontal en el mundo microbiano puede definirse, en sus términos más reducidos, como la transmisión de material genético de un microorganismo a otro de la misma $u$ otra especie, entendiéndose la transmisión como la herencia de la información genética transferida entre células. De esta manera, el flujo génico horizontal es significativo en términos que aporta efectivamente al potencial evolutivo del microorganismo que recibe genes de otro. Es claro, además, que la sola transferencia de genes no cumple con dicha condición, toda vez que no asegura la estabilización de la información genética transferida en el microorganismo receptor. Por ejemplo, un plasmidio puede ser transferido de un donador a un receptor, pero no establecerse en este último, por no darse en la célula las condiciones adecuadas para su replicación. En este contexto, se puede decir que tales eventos de transferencia pueden tornarse significativos en la medida que algún elemento translocable, asociado al plasmidio transferido, pueda transmitirse por transposición al genoma de la célula receptora.

Dentro del mundo microbiano, el tema del flujo génico horizontal ha sido tratado con mayor extensión e intensidad en relación a las bacterias, las cuales presentan, como facetas inherentes de su biología, las potencialidades y habilidades efectivas para intercambiar información genética a través de diferentes procesos: la conjugación, que involucra el flujo de genes desde una célula bacteriana donadora a otra célula receptora con la cual necesita estar en contacto; la transducción, que consiste en el intercambio de material genético entre células mediado por bacteriófagos y la transformación , en la cual el DNA libre de células es incorporado a las células receptoras. Si bien es cierto, hasta hoy se siguen aclarando aspectos de estos procesos a nivel celular y molecular, el énfasis de los estudios de transmisión horizontal en bacterias se ha desplazado hacia evaluar hasta que punto este proceso puede ocurrir en la naturaleza y a comprender mejor su contribución cuantitativa a la evolución bacteriana. Sin embargo, también hay razones de índole más práctica que motivan el estudiar aspectos del flujo génico horizontal, como por ejemplo entender como genes de resistencia a antibióticos pueden diseminarse rápidamente, incluso entre grupos bacterianos filogenéticamente alejados entre sí. Asimismo el tema también es de interés en relación a la evaluación de riesgo en conección con la liberación de microorganismos transgénicos, o sea modificados por ingeniería genética, la cual, dicho sea de paso, es una tecnología de alto impacto aplicado, que se deriva precisamente de nuestra habilidad para modular, junto con los microorganismos, la transmisión de genes entre entidades biológicas.

Para revisiones recientes sobre aspectos fundamentales del proceso de flujo génico horizontal, están los artículos de Heinemann (1991), Amábile-Cuevas y Chicurel (1992) y Syvanen (1994).

Dentro del contexto antes definido, se presentarán a continuación algunos avances recientes que, a mi juicio son novedosos. Sin embargo, cabe destacarque no se trata de una revisión exhaustiva, sino de destacar algunos artículos en relación al tema que se está analizando.

La transmisión horizontal de genes entre microorganismos se ha abordado por parte de varios grupos de investigadores, los cuales han podido evaluar frecuencias de transmisión ,bajo diversas condiciones de incubación, en lo referido a ambientes terrestres y acuá- 
ticos. En términos generales, los enfoques experimentales han consistido en realizar cruces genéticos "in situ", por ejemplo en rocas sumergidas en agua de río, y también a nivel de laboratorio en microcosmos, vale decir, situaciones experimentales que simulan las condiciones que los microorganismos encuentran en sus ambientes naturales, con la diferencia de poder controlar mucho más ajustadamente las variables que inciden sobre la transmisión genética. A esto deben agregarse los análisis genéticos clásicos, que apuntan a definir la presencia, estructura y funcionalidad de plasmidios, transposones, bacteriófagos lisogénicos u otras estructuras genéticas en diversos grupos microbianos, como asimismo su movilidad horizontal intraespecifica o a través de barreras taxonómicas ; contribuyen así, estos análisis, a proyectar la potencialidad de intercambio génico en la naturaleza.

Dos excelentes volúmenes (Levy \& Miller,1989; Fry \& Day, 1990) resumen los logros, hasta principios de esta década, en el área de investigación sobre transmisión genética en el ambiente.

Más recientemente, cabría destacar un énfasis en relación al intercambio génico en ambientes acuáticos, tanto por conjugación, transducción y transformación, procesos para los cuales se destacan frecuencias de transmisión máximas de $3 \times 10^{-1}, 1 \times 10^{-4}$ y $1 \times 10^{-2}$ respectivamente (Fry \& Day,1993). Dentro de este campo, la mayoría de los estudios versan sobre intercambio entre bacterias de agua dulce siendo mucho más escasos aquellos relativos a bacterias marinas. Sin embargo, esta deficiencia se está viendo superada. En efecto, han habido comunicaciones recientes y relevantes sobre conjugación en microcosmos marinos. Anglesetal.(1993) demostraron transmisión del plasmidio de amplio rango de hospedante RP1 desde el Vibrio sp. marino S14 a una cepa receptora, SW5, Gram negativa, también de origen marino y de superficie hidrofóbica en las condiciones experimentales usadas. Estos investigadores usaron una variante de la bacteria receptora para generar una biopelícula bacteriana sobre cuentas de vidrio, las cuales son puestas en contacto con las bacterias donadoras en un reactor de $20 \mathrm{ml}$ con agua de mar artificial. Se simulan, de esta manera, condiciones que se pueden encontrar, por ejemplo, en superficies sumergidas sobre las cuales se desarrolla una biopelícula rica en nutrientes y en la cual las bacterias que colonizan pueden estar en estrecho contacto, favoreciéndose así la conjugación. Es, por tanto, importante destacar que estos autores detectaron una frecuencia de transmisión de RP1 significativamente mayor entre células en la biopelícula, en comparación con células en la fase acuosa. Por otra parte, también puede darse transmisión plasmidial en condiciones de oligotrofía, que son comunes en el medio marino. A este respecto, Goodman et al. (1993), usando Vibrio sp. S14 y una cepa de Escherichia coli, demostraron transmisión deRP1 entre pares conjugativos homólogosy heterólogos, sobre la superficie de filtros en agua de mar artificial, en condiciones de privación de nutrientes, sin carbono, nitrógeno o fósforo agregado. Incluso, la transmisión de RP1 puede darse entre cepas de Vibrio $s p$. aunque las células donadoras y receptoras se mantengan en condiciones de privación nutricional, hasta por 15 días antes de que se efectúen los cruces genéticos. También, la transmisión del plasmidio se da en condiciones oligotróficas cuando se usa $E$. coli como donador en cruces con Vibrio sp. En forma similar al caso anterior, $\boldsymbol{E}$. coli puede actuar como donador de RP1 después de estar sometido a privación de nutrientes hasta por 3 días. Asimismo es notable el hecho que pueda darse transmisión tanto a $4^{\circ}$ $\mathrm{C}$ como a $26^{\circ} \mathrm{C}$.

Cabe destacar que la transmisión plasmidial en condiciones de microcosmos, también es extensible a enterobacterias patógenas del género Salmonella, para las cuales se ha descrito transmisión de RP4, sobre la superficie de un alga marina (Heim $\&$ Robeson, 1993) e intercambio génico con $\boldsymbol{E}$. coli, después de períodos prolongados de privación nutricional (Trincado \& Robeson, datos no publicados).

Más recientemente, Sandaa y Enger (1994) han estudiado la transmisión del plasmidio pRAS1, también de amplio rango de hospedante, que codifica pare multirresistencia a antibióticos y que fue encontrado er. una cepa de la bacteria patógena de salmónidos Aeromonas salmonicida. Estos autores demostraron la transmisión de pRAS1, en microcosmos que contenían sedimento marino natural, desde un donador $A$. salmonicida a bacterias propias del sedimento, tanto en presencia del antibióticos oxitetraciclina, para el cual pRAS1 codifica resistencia, como en ausencia de esta presión selectiva. La transmisión del plasmidio se da a altas frecuencias, en el orden de $3,3 \times 10^{-4}$ a $3,4 \times 10^{-1}$ transconjugantes por célula receptora, después de 8 días de incubación a $15^{\circ} \mathrm{C}$. En un contexto similar a éste, también se ha descrito la dispersión de plásmidos enterobacteriales a bacterias marinas, las cuales pueden ser seleccionadas por la adquisición de marcadores de resistencia a antibióticos (Robeson et al.,1990)

Cabe hacer notar también, que el flujo génico entre bacterias en microcosmos marinos, es factible mediante el proceso de transformación. En este contexto, Stewart \& Sinigalliano (1990), demostraron transformación de Pseudomonas stutzeri ZoBell con DNA cromosomal, en sedimentos marinos. Asimismo, se ha descrito la transformación de la bacteria marina Vibrio sp. D19 con DNA plasmidial (Jeffrey et al.,1990).

Una excelente revisión sobre transmisión génica 
por transformación natural en el ambiente, es la de Lorenz \& Wackernagel, 1994).

Los antecedentes antes expuestos indican claramente que la emergencia de bacterias resistentes a los antibióticos y la diseminación de dichas resistencias puede darse en el medio marino, en forma similar a como se ha dado la evolución de bacterias resistentes a agentes antimicrobianos en el ámbito clínico, idea que se ve reforzada por los resultados de Dahlberg y Hermansson (1995), quienes encontraron secuencias genéticas correspondientes a transposones conocidos, en DNA de comunidades bacterianas del medio marino. Esto, sin duda, da una señal de alerta para motivar el uso correcto de antibióticos en procesos de acuacultivos marinos, para así evitar un impacto negativo sobre el ambiente y la evolución de bacterias patógenas multirresistentes, que son una seria amenaza a los procesos productivos antes referidos.

Por otra parte, es destacable el hecho que la mayoría de los estudios relativos a la diseminación horizontal de información genética en bacterias se refieran al proceso de conjugación, lo cual puede ser un reflejo de la común noción que dicho proceso es el prevalente en la naturaleza; comparativamente, por tanto, se ha dedicado menos atención a los otros procesos de intercambio conocidos, particularmente a la transducción. Sin embargo, la contribución de la transducción al flujo génico horizontal puede haber sido subestimada hasta ahora. Por ejemplo, y para continuar con la temática de transmisión génica referida al medio acuático, es destacable el trabajo del grupo de R. Miller, que tempranamente abordó el estudio dela factibilidad de intercambio de marcadores genéticos por transducción en Pseudomonas aeruginosa en agua de lago, reportando frecuencias de transducción en el orden de $4 \times 10^{-6}$ ( Saye et al., 1987). Más recientemente, el mismo grupo ha encontrado que la frecuencia de transmisión puede aumentar en un factor de 100 en presencia de material particulado (Ripp \& Miller,1995). Además, haciendo uso de sondas de DNA, han encontrado una amplia distribución de fagos transductores y profagos correspondientes a Pseudomonas en muestras de agua de un lago, sedimentos, suelos y aguas servidas (Ogunseitan et al., 1995). En otro contexto, el de bacterias del ámbito clínico, también se han encontrado resultados indicativos de un alto potencial transductor; en efecto, Schicklmaier y Schmieger (1995) reportan un altísimo porcentaje $(93,7 \%)$ de fagos transductores generalizados provenientes de cepas lisógenas del complejo Salmonella typhimurium. Estos fagos transmiten genes cromosomales y también plasmidios,como el vector pBR325.

A la luz de los estudios referidos, queda claro que la contribución de la transducción al proceso de flujo génico entre poblaciones bacterianas, podría ser más importante de lo imaginado. En conección con esto, es notable el hecho que, en ambientes acuáticos se ha encontrado una gran abundancia de bacteriófagos (hasta $2,5 \times 10^{8}$ partículas virales/ml), algunos de los cuales podrían corresponder a fagos transductores (Bergh et al.,1989).

No se podría concluir esta breve revisión, sin hacer mención al trabajo de carácter tan central como lo es el de Heinemann y Sprague (1989), quienes a través de su investigación, han ampliado notablemente el horizonte de lo que puede significar, en términos evolutivos, el flujo horizontal de genes en el mundo microbiano, al describir la movilización de DNA, por conjugación, desde la bacteria $E$. coli a la levadura Saccharomyces cerevisiae, en lo que ha pasado a denominarse intercambio genético trans-reino. Estos investigadores demostraron que plasmidios bacterianos de amplio rango de hospedante, pueden mediar la transmisión de plasmidios seleccionables en $\boldsymbol{S}$. cerevisiae a frecuencias comparables a las registradas para cruces genéticos entre bacterias. Asimismo, encontraron que un plasmidio como el factor $\mathrm{F}$ de $\boldsymbol{E}$. coli, de rango de hospedante limitado también puede transferirse a $\boldsymbol{S}$. cerevisiae. En experimentos similares Inomata et al.(1994), también han demostrado flujo génico desde $\boldsymbol{E}$. coli a $\boldsymbol{S}$. kluyveri.

Estos resultados plantean la posibilidad de que los plasmidios bacterianos conjugativos jueguen un papel importante en la diseminación de información genética entre organismosfilogenéticamente muy separados, constituyéndose así en un factor significativo para la evolución biológica (Amábile-Cuevas \& Chicurel, 1992).

Para finalizar, cabe reiterar la importancia biológica básica del proceso de flujo génico horizontal en los microorganismos, como asimismo sus perspectivas aplicadas. En este contexto, es posible imaginar una acumulación creciente de datos respecto a transmisiones genéticas laterales entre distintos miembros del mundo microbiano, junto al inescapable desarrollo de nuevos instrumentos destinados a la modulación genética de los mismos.

\section{Agradecimientos}

Trabajo realizado con el apoyo de la Dirección General de Investigación y Post Grado. Universidad Católica de Valparaiso y de Fondecyt. 


\section{REFERENCIAS}

Amábile-Cuevas, C. F. \& Chicurell, M. E. (1992). plasmids and gene flux. Cell, 70:189-199.

Angles,M. L.; Marshall,K.C.; Goodman, A.E. (1993). Plașmid transfer between marine bacteria in the aqueous phase and biofilms in reactor microcosms. Appl. Environ. Microbiol., 59: 843-850.

Bergh, O.;Borsheim,K.Y.;Bratbak, G.; Heldal, M. (1989). High abundance of viruses found in aquatic environments. Nature,340: 467468 .

Dahlberg, C. \& Hermansson, M. (1995). Abundance of Tn3, Tn21, and $\mathrm{Tn} 501$ transposase (tnpA) sequences in bacterial community DNA from marine environments. Appl. Environ. Microbiol., 61: 3051-3056.

Fry, J.C. \& Day, M. J. (eds.). (1990). "Bacterial genetics in natural environments". Chapman and Hall, London.

Fry, J. C. \& Day, M.J. (1993). Overview of gene transfer in aquatic habitats. En: “Trends in Microbial Ecology". R. Guerrero and C. PedrósAlió (eds.). Spanish Society for Microbiology.

Goodman, A. E.; Hild, E.; Marshall, K. C.;Hermansson, M. (1993). Conjugative plasmid transfer between bacteria under simulated marine oligotrophic conditions. Appl. Environ. Microbiol., 59: 1035-1040.

Heim, A.K. \& Robeson,J.P. (1993). Transferencia de RP4 en Salmonella schottmuelleri: intercambio genético en superficies de microcosmos. Acta Microbiol. 4:101-106

Heinemann, J.A. \& Sprague Jr, G. F. (1989). Bacterial conjugative plasmids mobilize DNA transfer between bacteria and yeast. Nature, 340:205-209.

Heinemann, J. A. (1991). Genetics of gene transfer between species. Trends in Genetics, 7: 181-185.

Inomata, K.;Nishikawa, M.; Yoshida, K. (1994). The yeast Saccharomyces kluyveri as a recipient eukaryote in transkingdom conjugation: behavior of transmitted plasmids in transconjugants. $\mathrm{J}$. Bacteriol., 176:4770-4773.

Jeffrey, W. H.; Paul, J. H.; Stewart, G. J. (1990). Natural transformation of a marine Vibrio species by plasmid DNA. Microb. Ecol., 19: 259-268.
Levy, S. B. \& Miller, R. V. (eds.). (1989). "Gene transfer in the environment'. McGraw-Hill, New York.

Lorenz,M.G. \& Wackernagel, W. (1994). Bacterial gene transfer by natural genetic transformation in the environment. Microbiol. Rev. 58:563602

Ogunseitan, O.A.; Sayler, G. S.; Miller, R. V. (1995). Application of DNA probes to analysis of bacteriophage distribution patterns in the environment. Appl. Environ. Microbiol., 58: 2046-2052.

Ripp, S. \& Miller, R. V. (1995). Effects of suspended particulates on the frequency of transduction among Pseudomonas aeruginosa in a freshwater environment. Appl. Environ. Microbiol., 61: 1214-1219.

Robeson,J.P.; Grisolia,E; Godoy,S.V.; Quiroz,M. (1990). Evaluation of enterobacterial plasmid transfer to marine bacteria. Proceedings Second Biennial Water Quality Symposium: Microbiological Aspects pp.153158

Sandaa, R-A. \& Enger, O. (1994). Transfer in marine sediments of the naturally ocurringplasmidpRAS1 encoding multiple antibiotic resistance. Appl. Environ. Microbiol. 60: 4234-4238.

Saye, D.J.; Ogunseitan,O.; Sayler,G. S.; Miller, R. V.(1987). Potential for transduction of plasmids in a natural freshwater environment: effect of plasmid donor concentration and a natural microbial community on transduction in Pseudomonas aeruginosa. Appl. Environ Microbiol., 53:987-995

Schiklmaier, P. \& Schmieger, H. (1995). Frequency of generalized transducing phages in natural isolates of the Salmonella typhimurium complex. Appl. Environ Microbiol. 61:1637-1640.

Stewart, G.J. \& Sinigalliano, C. D. (1990). Detection of horizontal gene transfer by natural transformation in native and introduced species of bacteria in marine and synthetic sediments. Appl. Environ. Microbiol. 56: 1818-1824.

Syvanen, M. (1994). Horizontal gene transfer: evidence and possible consequences. Annu. Rev. Genet., 28:237-261. 